\title{
LANDFILL LEACHATE TREATMENT IN LITHUANIA
}

\author{
Lina Gelaziene \\ ECAT-Lithuania, Lithuania
}

\begin{abstract}
Around 6 million tons of non-hazardous waste and some 130-170 000 tons of hazardous waste is generated in Lithuania every year. Most of non-hazardous wastes are organic (2.1 millions tons) or domestic ( 1.7 million ton). Since no general waste incineration is used in Lithuania, the overall used method of waste disposal is landfilling. Most of the landfills are not designed or located properly. They pose a threat for both surface and groundwater in Lithuania.

The Lithuanian government has made environmental protection a priority concern in recent years. Bilateral and multilateral donors have made funding available for environmental projects.

Until 1998 no landfill in Lithuania had a landfill leachate treatment plant. Leachate was kept in the special storage places in the landfill, or collected and recirculated. In Vilnius, the capital of Lithuania, part of the landfill leachate is taken to the city's waste water treatment plant and part of it is recirculated. Competition for the landfill leachate plant was announced and hopefully in the near future Vilnius will have a real project for the landfill leachate treatment. Recirculation was carried out in Kaunas Lapes landfill too till the leachate treatment plant was built. Leachate is collected and kept in the ditches in the other three biggest cities of Lithuania - Klaipeda, Siauliai and Panevezys. Klaipeda, as all other cities, is looking for a cost effiective solution for the leachate treatment and Panevezys is thinking to clean the leachate in the city's waste water treatment plant. Biological leachate treatment is the idea of Siauliai municipality.
\end{abstract}




\section{LEACHATE TREATMENT IN KAUNAS LANDFILL}

Kaunas is the second largest city in Lithuania, having a population of approx. 430000 inhabitants. Since the year 1973 all municipal solid waste has been directed to the Lapes landfill, located $19 \mathrm{~km}$ outside Kaunas. The total landfill area is approx. 32.7 ha. The area of existing landfill is 12.5 ha and the area of the new under construction is 5.5 ha. Old part of the landfill is not provided with the bottom liner and drainage system for collection of leachate. It is estimated that during 25 years $2.4 \mathrm{mln}$. tons of municipal solid waste has been accumulated in the landfill. In 1991 a hydromonitoring program was started in Kaunas landfill. Results have shown that both groundwater and open water sources are very polluted in the surroundings. Because of that reason Kaunas Municipality started to implement landfill reconstruction program, which covers gas extraction and recultivation questions in the old part of the landfill. A new part of the landfill, constructed with bottom clay layer, plastic membrane and drainage system for collection of leachate, will start to operate in very near future. Very important part of this program is landfill leachate treatment. Leachate treatment plant was designed and built with the help of Danish governmental institutions. Joint stock company "Pramprojektas" has worked together with Danish company COWI Consult. This plant is the first landfill leachate treatment plant in Lithuania. Construction job was finished in October 1998. Total cost of the plant was $2.5 \mathrm{mln}$. Lt.

Average daily amount of the leachate in Kaunas landfill is around 80-

$100 \mathrm{~m}^{3}$. It is rich with organic materials and metals:

\begin{tabular}{|l|l|l|l|l|l|l|}
\hline $\mathrm{N}, \mathrm{tmg} / \mathrm{l}$ & $\mathrm{P}, \mathrm{tmg} / \mathrm{l}$ & $\mathrm{BOD}$ & $\mathrm{Cd}, \mathrm{mg} / \mathrm{l}$ & $\mathrm{Cr}, \mathrm{mg} / \mathrm{l}$ & $\mathrm{Pb}, \mathrm{mg} / \mathrm{l}$ & $\mathrm{Fe}, \mathrm{mg} / \mathrm{l}$ \\
\hline 1500 & 1 & 5000 & $0.001-$ & $0.01-1.2$ & $0.03-0.3$ & $0.46-64$ \\
& & & 0.0026 & & & \\
\hline
\end{tabular}

Amount of leachate depends on the weather conditions.

Biological treatment with the special filtration fields was selected for the landfill leachate treatment plant in Kaunas. Plant was designed based on average daily amount of the leachate, which in Kaunas landfill is around $82 \mathrm{~m}^{3}$. The unit works on sequence batch reactor (SBR) principle, aeration, biological nitrification and denitrification. Concentration of the sludge is 4.0 $\mathrm{kg} \mathrm{SS} / \mathrm{m}^{3}$. For the second stage of the treatment is used sand filter and the last stage is peat filter (Leca/myr). Talking about removal of organic pollutants, projected efficiency of the leachate treatment plant is $99.5 \%$.

\section{LEACHATE TREATMENT EXPERIMENT IN SIAULIAI LANDFILL}

Another example from Lithuania is leachate irrigation pilot project in Kairiai landfill in Siauliai. Project was prepared by ECAT-Lithuania, which is helping the municipality with technical and financial aid.

The landfill in Siauliai municipality was started in 1965. Since the start there has been no treatment of the leachate. Leachate has been caught in enlarged ditches and basins around the landfill. This stored leachate is highly concentrated in regards of chloride, nitrogen, phosphorous 
and metals. Since the leachate is too strong to be treated efficiently in an ordinary municipal waste water treatment plant, some kind of local treatment is necessary.

It was agreed with Siauliai municipality to select a cost effiective biological method for the landfill leachate treatment. It was decided to install four experimental plots (10x10 meters) and to plant them with Salix.

The first experimental plot with clay layer and drain system was installed and planted in the spring 1998.

\section{Laboratory tests}

Municipal laboratory of environmental investigations in Siauliai municipality carried out an experiment to determine leachate concentration, usefull for Salix irrigation. Methodological support for that experiment was provided from Stockholm University.

36 Salix viminalis cuttings with the length of $180-200 \mathrm{~mm}$ and the diameter of 14-16 $\mathrm{mm}$ were selected for the experiment. Objects of study were grown in the leachate and also in the soil. 4 diffierent solutions $-100 \%, 75 \%, 50 \%$ landfill leachate and control solution were prepared for the experiment.

Soil for the experiment was taken from the landfill area, where later the plants were supposed to grow. Salix viminalis, planted in the soil, were irrigated with $100 \%$ landfill leachate and with the fresh water.

Length of the experiment was 21 days. It was carried out in room temperature $18-20^{\circ} \mathrm{C}$.

The length of every plant roots and shoots as well as the color of the roots were measured after the experiment.

\section{Results}

Experimental results are shown in the following diagrams. 
ECOLOGICAL TECHNOLOGY AND MANAGEMENT

KALMAR, SWEDEN, September 22-24, 1999

The growth of Salix viminalis in the landfill leachate
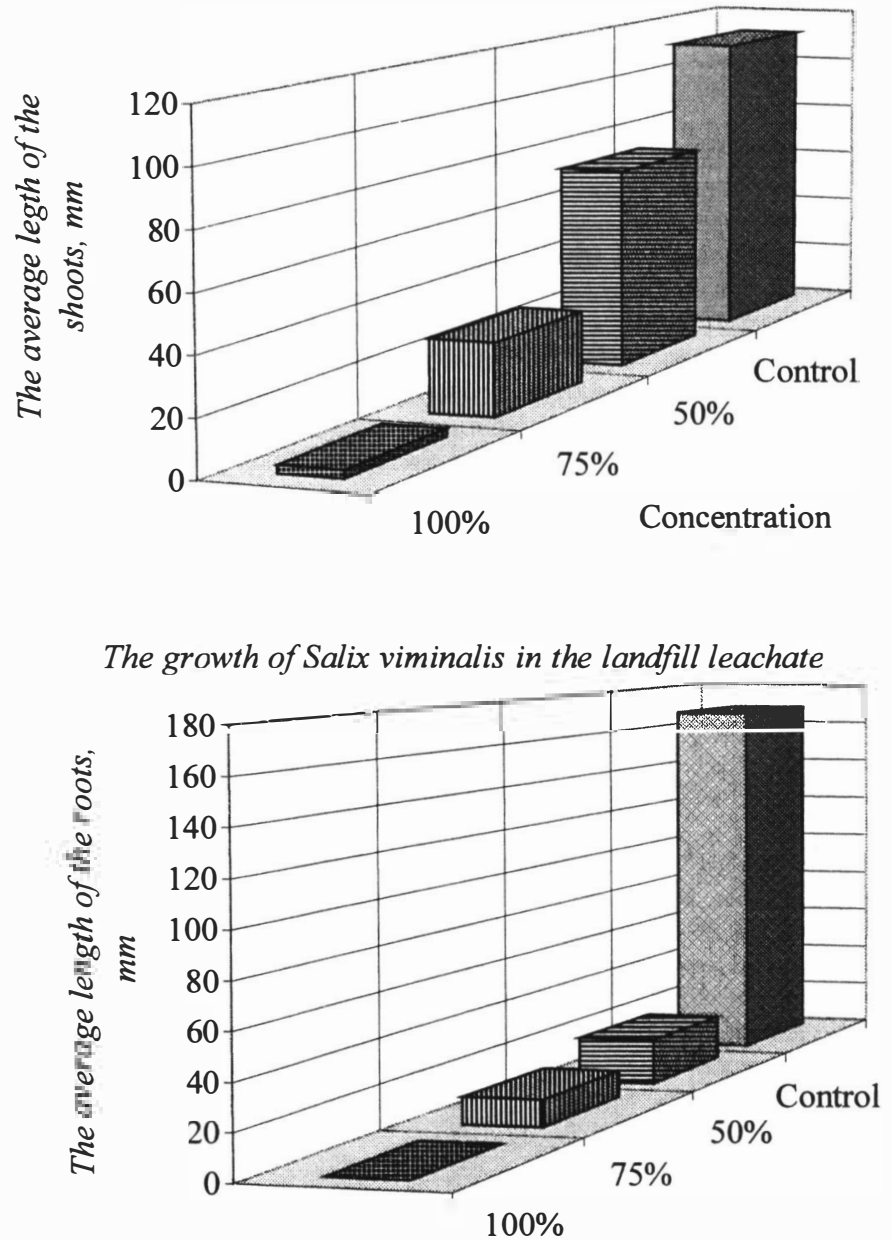

Concentration 
From the diagrams we can see that Salix viminalis irrigation with $100 \%$ of landfill leachate is not possible. Roots of the plants became deep brown colour, the average length of the shoots was only $3 \mathrm{~mm}$. In the leachate with concentration $75 \%$, plants had roots and shoots. Roots were 13 times shorter and shoots 4 times, comparing with control examples.

Plants, grown in the $50 \%$ concentration of the landfill leachate, had 8 times shorter roots and $35 \%$ shorter shoots than control examples. This concentration could be optimal for the irrigation of Salix viminalis.

Salix viminalis plants were also grown in the soil which was taken from the landfill area (the place where all experiment is planned to be made). Plants were irrigated with $100 \%$ landfill leachate. They had no roots and no shoots. Their buds became dry.

After the experiment conclusions were made that Salix viminalis to the landfill should be planted already with the roots. If there are no conditions to grow the roots, at the beginning plants should be irrigated with the fresh water. Later plants will be irrigated with diluted landfill leachate.

\section{Field experiment}

Salix were planted to the first experimental plot at the beginning of June, 1998. The length of cuttings $200 \mathrm{~mm}$, and diameter $10 \mathrm{~mm}$. Salix were planted in a rows every $0.7 \mathrm{~m}$, distance between rows $-0.7 \mathrm{~m}\left(2-3\right.$ plants in $\left.1 \mathrm{~m}^{2}\right)$.

240 cuttings were planted to the field. $90 \%$ of Salix took roots. Left $10 \%$ were replanted at the beginning of July. Plants were growing 5 months and in October they were $1.20-1.60 \mathrm{~m}$ of length. In the middle of the experimental plot the length of Salix reached only $0.10-0.40 \mathrm{~m}$. Reason for that probably was replanting of seedlings. Because of the wet summer, Salix were irrigated with the fresh water only four times during five months.

The actual irrigation will be carried out on small plots $10 \times 10$ meters for each test. It has been decided to establish four small plots. One of such plots was installed in spring 1998, other 2 will be prepared in 1999. Salix plants were planted and the first year they were irrigated only with the fresh water. The same will be done with the other 2 plots this year. It is planned for irrigation to use $5 \mathrm{~mm}$ of water in the first plot, $3 \mathrm{~mm}$ for the second plot and the third plot will be used as control plot. Duration of the experiment at least three seasons, possibly longer or until the first harvest.

Fourth plot is proposed for the Laqua project which is planned between Siauliai and Kristianstad municipalities.

The analyses of the leachate shows a strongly polluted water:

\begin{tabular}{|c|c|c|c|c|c|c|c|c|c|}
\hline $\mathrm{pH}$ & COD & BOD & P,tmg/l & $\begin{array}{l}\text { Chlori- } \\
\text { des, mg/l }\end{array}$ & $\begin{array}{l}\mathrm{NH} \\
\mathrm{mg} / \mathrm{l}\end{array}$ & $-\mathrm{N}, \mathrm{Ni}, \mathrm{mg} /$ & $\begin{array}{l}\mathrm{Pb}, \\
\mathrm{mg} / \mathrm{l}\end{array}$ & $\mathrm{Cr}, \mathrm{mg} / \mathrm{l}$ & $\begin{array}{l}\mathrm{Cu}, \\
\mathrm{mg} / \mathrm{l}\end{array}$ \\
\hline 8 & 690 & 50 & 1,5 & 5100 & 480 & 0,55 & 0,2 & 1,7 & 0,6 \\
\hline
\end{tabular}

The vegetation will use the nutrients in the water, and thus the contents of nitrogen, phosphorus and potassium is expected to be decreased. If the plants will not take up the contents in the leachate it could end up in the soil or groundwater which will be monitored. 
If the tests will show success, Siauliai municipality with the help of ECAT-Lithuania will look for the financial support for the full scale implementation.

\section{CONCLUSIONS}

1. Leachate from the landfills in Lithuania is very strong and landfill leachate treatment methods should be very specific for the different cases.

2. At the moment two different landfill leachate treatment models are tried out in the Lithuanian municipalities:

a) landfill leachate treatment in the municipal waste water treatment plant.

b) leachate treatment in the local landfill leachate treatment plant. 